\title{
Beta-defensin is a component of the endometrial immune defence in the mare
}

\author{
Sandra Schöniger, Hilke Gräfe and Heinz-Adolf Schoon \\ Institute of Pathology, Faculty of Veterinary Medicine, University Leipzig, An den Tierkliniken 33, 04103 Leipzig, Germany
}

\begin{abstract}
Summary
Defensins are antimicrobial peptides of the innate immune defence. The aim of the present study was to examine if $\beta$-defensin is expressed in the equine endometrium. Endometrial tissue samples were available from 29 mares. Performed were a histological examination $(n=28)$, RT-PCR $(n=29)$ and immunohistochemistry $(n=28)$. Mares aged $3-20$ years. Endometrosis was diagnosed in 20 mares; in the biopsy of 1 mare, endometrial glands could not be evaluated. Endometritis was observed in 12 and angiosclerosis in 21 mares. No endometrial alterations were found in 3 mares. Expression of equine $\beta$-defensin-1 mRNA was detected in all 29 mares and confirmed by sequencing in 11 cases. Immunostaining for $\beta$-defensin was detected in all 28 mares investigated; however, in 1 mare the surface and in another mare the glandular epithelium could not be evaluated. Immunopositive cell populations were the luminal epithelium ( $\mathrm{n}=27$ ), the glandular epithelium $(n=20)$, stromal cells $(n=6)$ and the vascular tunica media $(n=14)$. The majority of immunopositive cells were located within the luminal epithelium and the duct of the endometrial glands. The immunostainig of the epithelium was predominantly cytoplasmic and less frequently nuclear. Stromal cells showed a nuclear staining. The smooth muscle cells of the vascular tunica media displayed a cytoplasmic labelling in 13 mares and a nuclear staining in 1 mare. This study demonstrates the expression of $\beta$-defensins in the healthy and diseased equine endometrium and indicates that $\beta$-defensin contributes to the endometrial immune defence in the mare.
\end{abstract}

Keywords: $\beta$-defensin / endometrium / equine / mare / PCR / immunohistochemistry / reproduction

\section{Beta-Defensin ist ein Bestandteil der endometrialen Immunabwehr der Stute}

Beta-Defensine gehören zu den antimikrobiellen Peptiden der angeborenen Immunantwort. Das Ziel der vorliegenden Untersuchung war zu überprüfen, ob $\beta$-Defensin in dem equinen Endometrium vorliegt. Für die Studie standen Endometriumproben von 29 Stuten zur Verfügung. Die folgenden Untersuchungen wurden durchgeführt: eine histopathologische Untersuchung auf das Vorliegen von entzündlichen und/oder degenerativen endometrialen Veränderungen $(n=28)$, RT-PCR zum Nachweis von equinem $\beta$-Defensin-1 ( $n=29)$ und Immunhistologie zur Detektion von $\beta$-Defensin Protein $(n=28)$. Die Endometriumproben stammten von Stuten in einem Alter von $3-20$ Jahren. Eine gering- oder mittelgradige Endometrose wurde bei 20 Stuten diagnostiziert; in einer Gewebeprobe konnten die endometrialen Drüsen aufgrund des Vorliegens von Artefakten nicht untersucht werden. Bei 12 Stuten lag eine gering- oder mittelgradige Endometritis vor und bei 21 Stuten eine gering-, mittel- oder hochgradige Angiosklerose. Die Endometriumproben von 3 Stuten zeigten keine besonderen histopathologischen Befunde. Die mRNA von equinem $\beta$-Defensin- 1 konnte in den Endometriumproben aller 29 Stuten nachgewiesen werden. In 11 Fällen, bei denen Nativmaterial für die PCR verwendet wurde, wurde das Vorliegen von equinem $\beta$-Defensin- 1 durch eine Sequenzierung bestätigt. Ein positiver Nachweis von $\beta$-Defensin zeigte sich in allen immunhistologisch untersuchten Endometriumproben (28 Stuten); aufgrund von Artefakten konnte bei einer Stute das Oberflächenepithel und bei einer weiteren Stute das Drüsenepithel nicht beurteilt werden. Eine positive Immunoreaktivität war in dem Oberflächenepithel $(n=27)$, dem Drüsenepithel $(n=20)$, den Stromazellen ( $n=6)$ und in den glatten Muskelzellen der Tunica media der Gefäße $(n=14)$ nachweisbar. Die überwiegende Mehrzahl der immunopositiven Zellen befand sich in dem Oberflächenepithel und dem Epithel der Drüsenausführungsgänge. Die Epithelien zeigten überwiegend eine zyłoplasmatische Immunoreaktivität und nur in wenigen Fällen eine nukleäre Anfärbung. Die immunhistologische Reaktion der Stromazellen war ausschließlich im Zellkern lokalisiert. Bei 13 Stuten wiesen die glatten Muskelzellen der Tunica media eine zytoplasmatische und bei einer Stute eine nukleäre Immunoreaktivität auf. Mittels der durchgeführten Untersuchungen konnten $\beta$-Defensin mRNA und -Protein sowohl in histopathologisch unveränderten Endometriumproben als auch in endometrialem Gewebe mit entzündlichen und/oder degenerativen Veränderungen nachgewiesen werden. Somit stellt die endometriale Synthese von $\beta$-Defensin wahrscheinlich einen Bestandteil der uterinen Erregerabwehr der Stute dar.

Schlüsselwörter: $\beta$-Defensin / Endometrium / Pferd / Stute / PCR / Immunhistologie / Reproduktion

\section{Introduction}

Defensins are small cationic peptides $(3-5 \mathrm{kDa})$ composed of $18-45$ amino acids and are components of the innate immune defence (Schneider et al. 2005, Bruhn et al. 2011). They exert antimicrobial activity against bacteria, fungi and some enveloped viruses by disruption of microbial membranes (Ganz et al. 1990, Schneider et al. 2005, Bruhn 2009, Bruhn et al. 2011 1). In addition, they are opsonins, stimulate phagocytosis and act chemotactic for inflammatory and immune cells (Ganz et al. 1990, Schneider et al. 2005, Bruhn 2009, Bruhn et al. 2011 ). Based on structural characteristics, mammalian defensins are subclassified into three families, i.e. $\alpha$-defensins, $\beta$-defensins and $\theta$-defensins (Lehrer and Ganz 2002, Bruhn 2009, Bruhn et al. 2011). Beta-defensins occur in most mammalian species; they are synthetized by leukocytes and epithelial cells of multiple organs including the skin and mucous membranes (Schneider et al. 2005, Bruhn 2009, Bruhn et al. 2011 ). Their production is either continuously or induced by certain factors such as proinflammatory cytokines or the activation of Toll-like receptors (Bruhn 2009, Bruhn et al. 2011). In comparison, $\alpha$-defensins are only detected in some mam- 
malian species, are continuously produced and have a limited tissue distribution; they are predominantly expressed by neutrophils and intestinal Paneth cells (Schneider et al. 2005, Bruhn 2009, Bruhn et al. 2011 ). So far, functional $\theta$-defensin (synonym: retrocyclin) has been only detected in leukocytes of non-human primates (Bruhn 2009, Bruhn et al. 2011).

Only a few studies investigated the occurrence of defensins in the horse. Genomic sequences and transcripts of several $\alpha$ and $\beta$-defensins were identified (Davis et al. 2004, Looft et al. 2006, Bruhn et al. 2007, Bruhn 2009, Bruhn et al. 2009). Davis et al. (2004) examined tissues of a single healthy horse by RT-PCR and detected equine $\beta$-defensin-1 mRNA in multiple organs (lymph node, spleen, liver, lungs, small intestine, heart and kidney); endometrium was not investigated in this study. Bruhn (2009) screened several epithelial tissues of a single horse and umbilical cord of a foal for the transcription of the genomic sequences of the putative $\alpha$-defensin (DEFA5L) and several putative $\beta$-defensins (DEFB103, DEFL1, DEFL2 and DEFL3) that had been identified by Looft et al. (2006). DEFL2 and DEFL3 were detected in several tissues; DEFL3 was present also in the uterus. DEFA5L was found only in the small intestine and DEFB103 solely in the tongue epithelium; examined tissues did not contain DEFLl (Bruhn 2009). Betadefensin protein was observed in apocrine glands of the equine scrotum and oesophagus by immunohistochemistry using cross-reactive anti-human $\beta$-defensin-2 (oesophagus: Hornikkel et al. 2011 , scrotum: Yasui et al. 2007) and anti-human $\beta$-defensin-3 antibodies (Hornickel et al. 2011).

In mares, inflammatory and degenerative diseases of the endometrium, i.e. endometritis, endometrosis and angiosclerosis, are important factors of a reduced fertility and a low breeding success (Kenny and Doig 1986, Schoon et al. 1997). The contribution of defensins to the pathogenesis of endometrial diseases appears likely, since 1) in mucous membranes antimicrobial peptides including defensins provide the first line of immune defence (Schneider et al. 2005, Bruhn 2009), 2) infection and inflammation of mucous membranes is often associated with an induction/upregulation of certain defensins (Schneider et al. 2005), 3) some defensins can stimulate the proliferation of fibroblasts (Han et al. 2009) and 4) in human beings and mice an association between alterations in the expression of certain defensins and the development of inflammatory or degenerative diseases has been observed (Ganz et al. 1990, Yamaguchi et al. 2007, Bruhn 2009, Gersemann et al. 2012).
Thus, the characterization of the defensin expression in the equine endometrium could provide important insights into the pathogenesis of endometrial diseases and could reveal novel treatment options.

The aim of this study was to examine, 1) if $\beta$-defensin can be detected in the healthy and/or diseased equine endometrium and 2) in the case of a positive result, to characterize the cell population(s) expressing $\beta$-defensin. To the best of the authors' knowledge, this is the first case series investigating the expression of $\beta$-defensin in the equine endometrium and the first study on equine tissue analysing in parallel the expression of $\beta$-defensin transcripts and -protein.

\section{Materials and methods}

\section{Endometrial tissue samples}

Endometrial samples included post mortem collected tissue samples (11 mares) and biopsy submissions (18 mares, table 2). Tissue samples were obtained from mares (1-9 hours after their death) that were euthanized or had died spontaneously and were submitted for a post mortem examination at the Institute of Veterinary Pathology, University of Leipzig, Germany. From 14 mares native (frozen unfixed) tissue samples as well as formalin-fixed paraffin-embedded (FFPE) endometrium were collected, from 14 mares only FFPE tissue and from one mare only frozen tissue was available. Frozen tissue samples of endometrium were snap frozen in fluid nitrogen immediately after collection and stored at $-80^{\circ} \mathrm{C}$; these tissue samples were available from 29 mares. FFPE tissues were obtained by fixation of endometrial tissues in $4 \%$ buffered formalin for $24 \mathrm{hrs}$ followed by their embedding in paraffinblocks; FFPE tissue samples of endometrium were available from 28 mares.

\section{Histological evaluation}

Tissue samples of FFPE endometrium, available from 28 mares, were routinely processed, sectioned $(3 \mu \mathrm{m})$ and stained with haemalaun-eosin (HE) and Picro-Sirius Red stains. Sections were examined microscopically to diagnose inflammatory (endometritis) or degenerative (endometrosis, angiosclerosis) lesions, and to determine the functional morphology of the endometrial glands (Kenny and Doig 1986, Schoon et

\begin{tabular}{|c|c|c|c|c|}
\hline Gene & Primers (sequence $5^{\prime}$ to $3^{\prime}$ ) & $\begin{array}{l}\text { Amplicon } \\
\text { size (bp) }\end{array}$ & $\begin{array}{l}\text { Genbank } \\
\text { accession }\end{array}$ & Reference \\
\hline $\begin{array}{l}\text { Equine } \beta \text {-defensin-1 } \\
\text { (primer pair 1) }\end{array}$ & $\begin{array}{l}\text { F: TTGTCTTCCTGTTGCCTGTTCCAGG } \\
\text { R: TGCAGCATTTTGACCCAGGCAAG }\end{array}$ & 150 & NM 001081887 & - \\
\hline $\begin{array}{l}\text { Equine } \beta \text {-defensin- } 1 \\
\text { (primer pair } 2 \text { ) }\end{array}$ & $\begin{array}{l}\text { F: CCTTCCTCATTGTCTTCCTGTT } \\
\text { R: CTTCTTTCTGCAGCATTTTGAC }\end{array}$ & 167 & NM 001081887 & Davis et al. 2004 \\
\hline $\begin{array}{l}\text { GAPDH } \\
\text { (primer pair 1) }\end{array}$ & $\begin{array}{l}\text { F: TGAAGGGTGGCGCCAAGAGG } \\
\text { R: TGCCAGCCCCAGCATCGAAG }\end{array}$ & 567 & AF 157626 & Erdmann et al. 2007 \\
\hline $\begin{array}{l}\text { GAPDH } \\
\text { (primer pair 2) }\end{array}$ & $\begin{array}{l}\text { F: AGAAGGAGAAAGGCCCTCAG } \\
\text { R: GGAAACTGTGGAGGTCAGGA }\end{array}$ & 87 & NM 001163856 & Klein et al. 2011 \\
\hline
\end{tabular}

$\mathrm{GAPDH}=$ Glycerinaldehyd-3-phosphat-dehydrogenase; $\mathrm{F}=$ forward primer; $\mathrm{R}=$ reverse primer 
al. 1992, Schoon et al. 1997). Endometritis and endometrosis were diagnosed by the use of HE stained tissue sections. Endometritis was classified as acute suppurative, subacute suppurative and non-suppurative. Acute suppurative endometritis was characterized by infiltration of the endometrium with mainly neutrophils and only occasional lymphocytes and plasma cells. In subacute suppurative endometritis, neutrophils were admixed with similar amounts of lymphocytes and/or plasma cells. Non-suppurative endometritis was defined as infiltration of the endometrium solely by lymphocytes and/or plasma cells. In case the inflammatory cells were restricted to the stratum compactum, the endometritis was diagnosed as superficial endometritis.

For the diagnosis of endometrosis and angiosclerosis (arterioand phlebosclerosis) HE and Picro-Sirius Red stained tissue sections were used. Endometrosis is characterized by the presence of periglandular fibrosis (Schoon et al. 1997). The degree of angiosclerosis was determined separately for arteries/arterioles and veins/venules by the use of a scoring system and the calculation of the vascular degeneration index (VDI). From each mare three representative arterial and venous vessels were evaluated in detail for the calculation of the VDI. In regard to arteries/arterioles, increased deposition of collagen and/or elastic fibres was scored separately for each vascular layer, i.e. intima (I), media (M) and adventitia (A): $0=$ no alterations, $1=$ mild increase, $2=$ moderate increase, $3=$ marked increase. The assigned scores were used for the calculation of the VDI $(\mathrm{VDI}=\mathrm{I}+\mathrm{M}+\mathrm{A} ; \mathrm{O}=$ no arteriosclerosis, $1-3=$ mild arteriosclerosis, $4-7=$ moderate arteriosclerosis, $8-10=$ marked arteriosclerosis). Since in veins and venules, it is difficult to separate $I$ and $M$ or $M$ and $A$, the increased deposition of collagen and/or elastic fibres in veins/venules was scored in reference to the entire vessel wall $10=$ no alterations, $1=$ mild increase, $2=$ moderate increase, $3=$ marked increase). Thus for veins/venules, the VDI is equal to the determined scores $(0=$ no phlebosclerosiss, $1=$ mild phlebosclerosis, 2 =moderate phlebosclerosis, $3=$ marked phlebosclerosis). Furthermore, it was evaluated if the sclerosis was caused by deposition of collagen fibers (fibrosis), ela-

\begin{tabular}{|c|c|c|c|c|c|c|c|}
\hline No. & $\begin{array}{c}\text { Endometrium } \\
\text { sample }\end{array}$ & Age (y) & $\begin{array}{l}\text { Glandular } \\
\text { morphology }\end{array}$ & Endometritis & Endometrosis & Arteriosclerosis & Phlebosclerosis \\
\hline 1 & PME & 5 & prolif-secr & - & - & - & - \\
\hline 2 & PME & 4 & prolif-secr & - & - & - & - \\
\hline 3 & PME & 4 & secr & - & - & - & - \\
\hline 4 & PME & 18 & secr & - & + & +++ ef & +++ ef \\
\hline 5 & PME & 18 & secr & $+L P$, superf & ++ & + ef & ++ ef \\
\hline 6 & PME & 14 & prolif & - & ++ & - & + ef \\
\hline 7 & PME & 12 & secr & - & ++ & ++ ef & ++ ef \\
\hline 8 & PME & 15 & prolif-secr & - & ++ & ++ ef & ++ ef \\
\hline 9 & PME & 10 & prolif & + subacute supp & + & +++ , ef &,$++ \mathrm{e}$ \\
\hline 10 & PME & 12 & prolif & $+L P$, superf & + & - & ++ , ef \\
\hline 11 & PME & 3 & NA & NA & NA & NA & NA \\
\hline 12 & B & $>10$ & prolif & - & + & $+f$ & - \\
\hline 13 & B & 6 & prolif & - & - & - & - \\
\hline 14 & B & 9 & NA & - & NA & ++ ef & +++ ef \\
\hline 15 & B & 18 & prolif & $+L P$, superf & ++ & ++ ef & - \\
\hline 16 & B & 15 & secr & ++ subacute supp, superf & ++ & ++ ef & +++ ef \\
\hline 17 & B & 11 & prolif-secr & + subacute supp, superf & + & + ef & ++ ef \\
\hline 18 & B & 11 & maldiff & + subacute supp, superf & + & $+\mathrm{e}$ & + ef \\
\hline 19 & B & NK & secr & ++ acute supp, superf & + & ++ ef & ++ ef \\
\hline 20 & B & NK & secr & - & - & + ef & ++ ef \\
\hline 21 & B & 18 & prolif & - & ++ & - & - \\
\hline 22 & B & 7 & prolif & + subacute supp, superf & - & - & - \\
\hline 23 & B & NK & secr & $+\mathrm{LP}$ & + & - & - \\
\hline 24 & B & 6 & prolif & - & - & + ef & - \\
\hline 25 & B & NK & maldiff & $+\mathrm{LP}$ & ++ & - & + ef \\
\hline 26 & B & 16 & secr & - & + & $+\mathrm{e}$ & + ef \\
\hline 27 & B & 6 & prolif & - & + & ++ ef & + ef \\
\hline 28 & B & 20 & secr & - & ++ & ++ ef & ++ ef \\
\hline 29 & B & 16 & secr & ++ subacute supp & ++ & + ef & + ef \\
\hline
\end{tabular}

PME = collected during post mortem examination; $\mathrm{B}=$ biopsy; $y=$ years; secr = secretory; prolif = proliferative; prolif-secr = proliferative-secretory; maldiff $=$ maldifferentiated; $\mathrm{NK}=$ not known; $\mathrm{NA}=$ not applicable; $-=$ absent; $+=$ mild $;++=$ moderate; $+++=$ marked; $\mathrm{LP}=$ lymphocytic and plasma cellular; supp $=$ suppurative; superf $=$ superficial; ef $=$ elastofibrosis; $\mathrm{e}=$ elastosis $; f=$ fibrosis 
stin fibers (elastosis) or both fibre types with a predominance of elastic fibres (elastofibrosis) or collagen fibres (fibroelastosis) (modified according to Ludwig et al. 2001).

The results of the evaluation of degenerative changes in arteries and veins (absent, mild, moderate or marked arterioand/or phlebosclerosis) were used to determine the total degree of vascular degenerative lesions (absent, mild, moderate or marked angiosclerosis).

\section{RT-PCR for the detection of equine $\beta$-defensin- 1 mRNA}

RT-PCR was performed on frozen tissue and FFPE tissue (table 2).

\section{Primers}

The applied primers are summarized in table 1. For the detection of equine $\beta$-defensin-1, two different pairs of primers were used. For the design of the 1 st primer pair, predicted cDNA sequences for equine $\beta$-defensin- 1 were obtained from NCBI Genbank (www.ncbi.nlm.nih.gov/Genbank/) and the primer design program (primer 3) was used. The 2 nd primer pair was obtained from the literature (Davis et al. 2004). In all tissue samples, the expression of the housekeeping gene GAPDH was determined for assessment of the quality of the mRNA samples. Primer pairs for the detection of an amplicon of $567 \mathrm{bp}$ (Erdmann et al. 2007, only native tissue) and an amplicon of $87 \mathrm{bp}$ (Klein et al. 2011, native and FFPE tissue) were used. The former primer pair, published for the detection of GAPDH mRNA in bovine tissue (Erdmann et al. 2007), can be used for the detection of GAPDH mRNA in equine tissues as well due to the existence of a high sequence homology (92.8\%).

\section{RNA extraction}

To extract the total mRNA from the frozen tissue samples PeqGold, RNA Pure ${ }^{\mathrm{TM}}$ was used according to the guidelines of the manufacturer (Peqlab Itd., Sarisbury Green, UK). For extraction of the total mRNA from FFPE tissue, three to four $5 \mu \mathrm{m}$ thick tissue sections were deparaffinized by the use of xylol. The total mRNA was obtained by the use of RNeasy FPPE kit (Qiagen) per manufacturer's instructions. The amount of extracted RNA was measured by photometry (260/280nm).

\section{Reverse transcription}

The reverse transcription of mRNA to first-strand cDNA was performed by the use of the Moloney Murine Leukemia Virus reverse transcriptase (M-MLV RT) (Promega, Madison, WI, USA) and random primer (Invitrogen, Carlsbad, CA, USA) using a standardized method.

cDNA amplification

cDNA amplification was performed in a $25 \mu \mathrm{l}$ reaction mixture. For the detection of equine $\beta$-defensin- 1 , the reaction mixture contained $1 \mu$ l of generated cDNA, $0.2 \mathrm{mM}$ of dNTP mix (Roche, Mannheim, Germany), $1 \mu \mathrm{M}$ of sense and antisense primers (Invitrogen), $2 \mathrm{mM} \mathrm{MgCl}$ (Roche), $2.5 \mu \mathrm{l}$ of PCR buf- fer (10x, Roche) and $2.5 \mathrm{U}$ of TaqDNA polymerase (Roche) (modified after Davis et al. 2004 and Bruhn 2009). For the detection of GAPDH mRNA, the reaction mixture contained $1 \mu \mathrm{l}$ of generated cDNA, $0.2 \mathrm{mM}$ of dNTP mix (Roche), $0.4 \mu \mathrm{M}$ sense and antisense primers (Invitrogen), PCR buffer with $1.5 \mathrm{mM} \mathrm{MgCl}(10 \mathrm{x}$, Roche) and $0.5 \mathrm{U}$ Taq DNA polymerase (Roche). To rule out DNA contamination, reaction mixtures with replacement of cDNA by DEPC water were used.

For all applied primer pairs (equine $\beta$-defensin-1, GAPDH), thermocycling parameters included initial denaturation (3 min, $\left.94^{\circ} \mathrm{C}\right), 35$ cycles of denaturation $\left(50 \mathrm{sec}, 94^{\circ} \mathrm{C}\right)$, annealing $\left(50 \mathrm{sec}, 56^{\circ} \mathrm{C}\right)$ and extension $\left(1 \mathrm{~min}, 72^{\circ} \mathrm{C}\right)$, final elongation $\left(10 \mathrm{~min}, 72^{\circ} \mathrm{C}\right.$ ) and cooling to $4^{\circ} \mathrm{C}$; a PTC 200 Thermo cycler (MJ Research, St Brun, Canada) was used. The amplified products were separated in an $1.5 \%$ agarose gel using Gene Ruler TM 50bp/100bp DNA ladder (Fermentas, St. Leon-Rot, Germany) as a molecular marker, stained with Ethidiumbromide (Carl Roth, Karlsruhe, Germany) or Gel Red Nucleic Acid Stain (Biotium, Brussels, Belgium) and detected in a BioRad Detection System (ChemiDocXRS, UV application).

\section{Sequencing of PCR products}

Sequencing was performed on 11 cases. The equine $\beta$-defensin-1 PCR products were purified and sequenced at the Interdisciplinary Centre for Clinical Research (IZKF), Leipzig, Germany to confirm the specificity of the PCR product. For sequencing, both primer pairs were used in 8 cases and primer pair 1 in 3 cases (table 3). In the negative controls, the cDNA was omitted.

\section{Immunohistochemistry for the detection of beta-defensin} Method

Sections of FFPE tissues were dewaxed, rehydrated and treated with $3 \% \mathrm{H}_{2} \mathrm{O}_{2}$ in methanol for 30 min at room temperature (RT). As primary antibody, a cross-reactive anti-human $\beta$-defensin-2 antibody (1:250-1:500; no pretreatment, Biologo, Kronshagen, Germany) was used. The primary and secondary antibodies and the PAP-complex were diluted in tris-buffered saline (TBS) containing $20 \%$ porcine serum. Sections were incubated with the primary antibody overnight at $4^{\circ} \mathrm{C}$ and rinsed thoroughly with TBS. Subsequently, sections were treated with swine anti-rabbit immunoglobulin $G$ (1:100; Dianova, Hamburg, Germany) for 30 minutes at RT. After a further washing step with TBS, rabbit-PAP-complex (1:100; Dianova) was applied for 30 minutes at RT. The chromogen 3,3'-diaminobenzidine-tetrahydrochloride (DAB; Fluka Feinchemikalien, Neu Ulm, Germany) was used.

Slides were counterstained with Papanicolaou's solution (Merck, Darmstadt, Germany). As a positive control, a biopsy of human endometrium was used; permission for taking the biopsy sample was obtained from the patient. For each immunolabelled section, the following negative controls were performed, i.e. replacement of the primary antibody by 1) the solvent, i.e. TBS containing $20 \%$ porcine serum, 2) rabbit nonimmune serum diluted in TBS containing 20\% porcine serum, and 3) a non-related rabbit anti-human polyclonal antibody, i.e. anti-glial fibrillary acid protein (GFAP) antibody 
(1: 250, no pretreatment, Dako, Hamburg, Germany). GFAP immunostaining was performed with the same PAP-method that had been used for $\beta$-defensin immunolabelling; negative controls (replacement of the primary antibody by the solvent and rabbit nonimmune) were included. The positive immunostaining of nerve fibers within examined sections served as internal positive control.

\section{Evaluation of the immunosignal}

The immunostaining of the luminal epithelium, the epithelium of ducts, mid and basal portions of the endometrial glands and the stromal cells was evaluated by image analysis. For each of these cell populations, digital images were taken from 3 representative areas of the immunostained section ( $S$ Plan Apo 40x objective, Olympus $\mathrm{BH} 2$ microscope) using an Olympus DP12 camera and the Soft Imaging System $5^{\circledR}$ (Olympus). Within each representative area, the immunopositive and immunonegative cells were counted with Adobe Photoshop, CS4, analysing at least 100 cells, the number of counted cells varied between 100 and 170 cells. For each examined cell population, the percentage of immunopositive cells was calculated.

\section{Results}

\section{Signalment of mares}

Endometrial and uterine tissue samples were collected from 29 mares that aged $3-20$ years. The age of 1 mare was reported as older than 10 years, the age of 4 mares was not known (table 2). The breed of 11 mares was known including 5 Haflinger, 1 Islandpony, 1 Trakehner, 1 Sachsen-Anhaltiner 1 Shire-Horse, 1 Warmblut and 1 Brandenburger. The breed of 18 mares was not reported.

\section{Histological evaluation}

Histological examination was performed on the FFPE endometrial samples that were available from 28 mares (table 2). In the

\begin{tabular}{|c|c|c|c|}
\hline No. & PCR: equines $\beta$-defensin- 1 & Sequencing & IHC: $\beta$-defensin \\
\hline 1 & $+($ Frozen: 1) & $+($ Frozen: 1) & + \\
\hline 2 & $+($ Frozen: 1) & NP & + \\
\hline 3 & $+($ Frozen: 1) & $+($ Frozen: 1) & + \\
\hline 4 & $+($ Frozen: 1,2$)$ & $+($ Frozen: 1, 2) & + \\
\hline 5 & $+($ Frozen: 2) & NP & + \\
\hline 6 & $+($ Frozen: 1,2$)$ & $+($ Frozen: 1, 2) & + \\
\hline 7 & $+($ Frozen: 1) & NP & + \\
\hline 8 & $+($ Frozen: 1,2$)$ & $+($ Frozen: 1, 2) & + \\
\hline 9 & $+($ Frozen: 1, 2) & $+($ Frozen: 1, 2) & + \\
\hline 10 & $+($ Frozen: 1, 2) & $+($ Frozen: 1, 2) & + \\
\hline 11 & $+($ Frozen: 1,2$)$ & $+($ Frozen: 1, 2) & NP \\
\hline 12 & $+($ Frozen: 1, 2; FFPE: 2) & $+($ Frozen: 1, 2) & + \\
\hline 13 & $+($ Frozen: 1, 2; FFPE: 2) & $+($ Frozen: 1, 2) & + \\
\hline 14 & $+($ Frozen: 1, 2; FFPE: 2) & $+($ Frozen: 1) & + \\
\hline 15 & $+($ Frozen: 2; FFPE: 2) & NP & + \\
\hline 16 & $+($ FFPE: 1, 2) & NP & + \\
\hline 17 & $+($ FFPE: 1, 2) & NP & + \\
\hline 18 & $+($ FFPE: 1) & NP & + \\
\hline 19 & $+($ FFPE: 1,2$)$ & NP & + \\
\hline 20 & $+($ FFPE: 1, 2) & NP & + \\
\hline 21 & $+($ FFPE: 1, 2) & NP & + \\
\hline 22 & $+($ FFPE: 1, 2) & NP & + \\
\hline 23 & $+($ FFPE: 1,2$)$ & NP & + \\
\hline 24 & $+($ FFPE: 1, 2) & NP & + \\
\hline 25 & $+($ FFPE: 1,2$)$ & NP & + \\
\hline 26 & $+($ FFPE: 1,2$)$ & NP & + \\
\hline 27 & $+($ FFPE: 1, 2) & NP & + \\
\hline 28 & $+($ FFPE: 1, 2) & NP & + \\
\hline 29 & $+($ FFPE: 1,2$)$ & NP & + \\
\hline
\end{tabular}

$1=$ primer pair 1 (table 1); $2=$ primer pair 2 (table 1); frozen = unfixed frozen tissue; FFPE = formalin-fixed, paraffin embedded tissue;

$\mathrm{IHC}=$ immunohistochemistry; NP = not performed 
FFPE endometrial tissue of 1 mare (No. 14), the glandular functional morphology and glandular alterations could not be evaluated due to the small size and poor quality of the sample.

The functional morphology of the endometrial glands was secretory in 11, proliferative in 10 and proliferative-secretory in 4 mares. In 2 mares, a maldifferentiation of endometrial glands was diagnosed, i.e. glands were "irregular secretory" in 1 mare and "completely irregular" in the other mare.

The endometrium of 3 mares displayed no significant alterations. Endometritis was diagnosed in 12 mares; it was mild in 9 and moderate in 3 mares. Acute suppurative endometritis was observed in 1 horse, subacute suppurative endometritis in 6 horses and non-suppurative lymphocytic and plasmacellular endometritis in 5 horses. Eight mares had a superficial endometritis. Endometrosis was observed in 20 mares, it was mild in 10 and moderate in the remaining 10 mares. Mild, moderate or marked angiosclerosis was observed in 21 horses. Most of these horses $(n=15)$ showed the concurrent presence of arterio- and phlebosclerosis, in 3 horses only veins and in 3 horses only arteries showed mild or moderate degenerative lesions. Arteriosclerosis was mild in 8, moderate in 8 and marked in 2 horses. Phlebosclerosis was mild in 6, moderate in 9 and marked in 3 horses. In the majority of horses with degenerative vascular lesions, a concurrent endometrosis was diagnosed ( $n=18)$. In 10 horses, the simultaneous presence of endometritis, endometrosis and angiosclerosis was noted.

\section{RT-PCR for the detection of equine $\beta$-defensin- 1}

The results of the PCR are summarized in table 3. In all mares of this study $(n=29)$, the endometrial expression of equine $\beta$-defensin- 1 mRNA was confirmed by the detection of a distinct band at $150 \mathrm{bp}$ (primer pair 1) or $167 \mathrm{bp}$ (primer pair 2, Davis et al. 2004) within frozen and/or FFPE tissue (Figs. 1 and 2$)$. Most tissue samples $(n=22)$ were examined by the use of both primer pairs, five were examined by the use of primer pair 1 and two by the use of solely primer pair 2. Contamination with cDNA was ruled out due the absence of a band in the negative control (replacement of cDNA by DEPC water). The quality of the mRNA was confirmed by the amplification of GAPDH mRNA (Figs. 1 and 2). Sequencing of the PCR pro-

\begin{tabular}{|c|c|c|c|c|c|}
\hline No. & Luminal epithelium & Epithelium of gland ducts & Epithelium of mid glands & Epithelium of basal glands & Stromal cells \\
\hline 1 & $++C_{1}-N$ & $+\mathrm{C}_{1}(+) \mathrm{N}$ & $-C_{1}(+) N$ & $-C_{1}-N$ & $-C_{1}+N$ \\
\hline 2 &,$+++ C_{,}-N$ & $-C_{1}(+) N$ & $-C_{1}(+) \mathrm{N}$ & $-C_{1}-N$ & $-C_{1}+N$ \\
\hline 3 & $++C_{1}-N$ & $+C_{1}-N$ & $-C_{1}-N$ & $-C_{1}-N$ & $-C_{1}+N$ \\
\hline 4 & $+C,-N$ & $++C_{1}-N$ & $-C_{1}-N$ & $-C_{1}-N$ & $-C_{1}-N$ \\
\hline 5 & $+++C_{1}-N$ & $(+) C,(+) \mathrm{N}$ & $-C_{1}(+) N$ & $-C_{1}-N$ & $-C_{1}(+) N$ \\
\hline 6 & $++C_{1}(+) N$ & $++C_{1}(+) N$ & $-C_{1}+N$ & $-C_{1}+N$ & $-C_{1}(+) N$ \\
\hline 7 & $(+) C,-N$ & $(+) C,-N$ & $-C_{1}-N$ & $-C_{1}-N$ & $-C_{1}-N$ \\
\hline 8 & $(+) C,-N$ & $-C_{1}-N$ & $-C_{1}-N$ & $-C_{1}-\mathrm{N}$ & $-C_{1}-N$ \\
\hline 9 & $+++C_{1}-N$ & $++C_{1}-N$ & $-C_{1}-N$ & $-C_{1}-\mathrm{N}$ & $-C_{1}(+) N$ \\
\hline 10 & $+++C_{1}-N$ & $+C_{1}-N$ & $-C_{1}-N$ & $-C_{1}-N$ & $-C_{1}-N$ \\
\hline 12 & $+++C_{1}-N$ & $++C_{1}-N$ & $-C_{1}-N$ & $-C_{1}-N$ & $-C_{1}-N$ \\
\hline 13 & $(+) C_{1}-N$ & $-C_{1}-N$ & $-C_{1}-N$ & $-C_{1}-N$ & $-C_{1}-N$ \\
\hline 14 & $+C,-N$ & NA & NA & NA & $-C_{1}-N$ \\
\hline 15 & $+C_{1}-N$ & $(+) C,-N$ & $-C_{1}-N$ & $-C_{1}-N$ & $-C_{1}-N$ \\
\hline 16 & $(+) C_{1}-N$ & $++C_{1}-N$ & $-C_{1}-N$ & $-C_{1}-N$ & $-C_{1}-N$ \\
\hline 17 & $+C_{1}-N$ & $-C_{1}-N$ & $-C_{1}-N$ & $-C_{1}-N$ & $-C_{1}-N$ \\
\hline 18 & $++C_{1}-N$ & $+C_{1}-N$ & $-C_{1}-N$ & $-C_{1}-N$ & $-C_{1}-N$ \\
\hline 19 & NA & $-C_{1}-N$ & $-C_{1}-N$ & $-C_{1}-N$ & $-C_{1}-N$ \\
\hline 20 & $+C_{1}-N$ & $-C_{1}-N$ & $-C_{1}-N$ & $-C_{1}-N$ & $-C_{1}-N$ \\
\hline 21 & $++C_{1}-N$ & $(+) C,-N$ & $-C_{1}-N$ & $-C_{1}-\mathrm{N}$ & $-C_{1}-N$ \\
\hline 22 & $+C_{1}-N$ & $(+) C,-N$ & $-C_{1}-N$ & $-C_{1}-N$ & $-C_{1}-N$ \\
\hline 23 & $+\mathrm{C}_{1}(+) \mathrm{N}$ & $+C_{1}-N$ & $-C_{1}-N$ & $-C_{1}-N$ & $-C_{1}-N$ \\
\hline 24 & $++C_{1}-N$ & $-C_{1}-N$ & $-C_{1}-N$ & $-C_{1}-N$ & $-C_{1}-N$ \\
\hline 25 & $++C_{1}-N$ & $-C_{1}-N$ & $-C_{1}-N$ & $-C_{1}-N$ & $-C_{1}-N$ \\
\hline 26 & $++C_{1}-N$ & $-C_{1}(+) N$ & $-C_{1}+N$ & $-C_{1}+N$ & $-C_{1}-N$ \\
\hline 27 & $+++\mathrm{C},-\mathrm{N}$ & $++C,-N$ & $-C_{1}-N$ & $-C_{1}-N$ & $-C_{1}-N$ \\
\hline 28 & $+++C_{1}-N$ & $+C_{1}-N$ & $-C_{1}-N$ & $-C_{1}-N$ & $-C_{1}-N$ \\
\hline 29 & $++C_{1}-N$ & $+++C_{1}-N$ & $++C_{1}-N$ & $-C_{1}-N$ & $-C_{1}-N$ \\
\hline
\end{tabular}


duct obtained from native (frozen unfixed) tissue samples $(n=11)$ confirmed the specificity of the PCR-product (table 3).

\section{Immunohistochemistry for the detection of $\beta$-defensin}

The results of the immunohistochemistry on the endometrial tissue samples of 28 mares are summarized in table 4. Immunopositive cell populations were the luminal and glandular

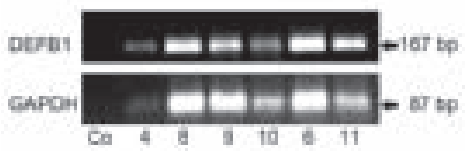

Fig. 1 RT-PCR, frozen endometrium: Detection of equine $\beta$-defensin-1 (DEFB1) in the endometrium of 6 mares (mares Nos. 4, 6, 8, 9, 10, 11; primer pair: Davis et al. 2004). For comparison, GAPDH expression is depicted. In the negative control (Co), cDNA was replaced by $\mathrm{H}_{2} \mathrm{O}$. Representative data are shown.

RT-PCR an Nativgewebe: Nachweis von equinem $\beta$-Defensin- 7 (DEFB 1) im Endometrium von 6 Stuten (Stuten Nr. 4, 6, 8, 9, 10, 11 ; Primer-Paar: Davis et al. 2004). Zum Vergleich wurde GAPDH nachgewiesen. In der Negativkontrolle (Co) wurde die $\mathrm{cDNA}$ durch $\mathrm{H}_{2} \mathrm{O}$ ersetzt. Die Abbildung zeigt repäsentative Befunde.

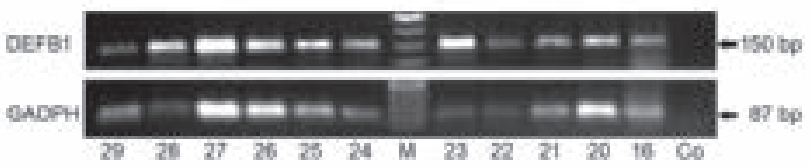

Fig. 2 RT-PCR, FFPE tissue: Detection of equine $\beta$-defensin- 1 mRNA (DEFB1) in the endometrium of 11 mares (mares Nos. 16, 20-29). For comparison, GAPDH expression is depicted. In the negative control (Co), cDNA was replaced by $\mathrm{H}_{2} \mathrm{O}$. Representative data are shown.

RT-PCR an FFPE Gewebe: Nachweis von equinem $\beta$-Defensin- 1 (DEFB 1) in dem Endometrium von 11 Stuten (Stuten Nr. 16, 20-29). Zum Vergleich wurde GAPDH nachgewiesen. In der Negativkontrolle (Co) wurde die cDNA durch $\mathrm{H}_{2} \mathrm{O}$ ersetzt. Die Abbildung zeigt repäsentative Befunde.

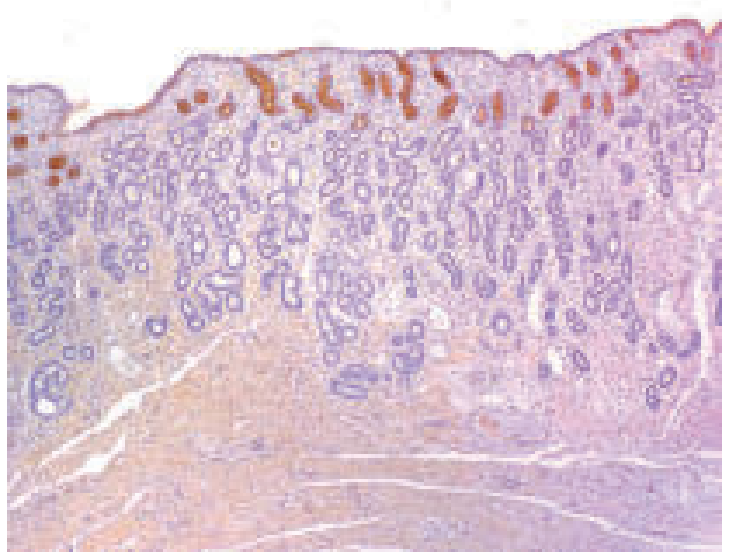

Fig. 3 Immunohistochemistry for the detection of $\beta$-defensin: The highest numbers of immunopositive cells are located within the luminal epithelium and ducts of endometrial glands (mare No. 3). Immunhistologischer Nachweis von $\beta$-Defensin: Die größte Anzahl immunopositiver Zellen befindet sich im Oberflächenepithel und in den Drüsenausführungsgängen (Stute Nr. 3).

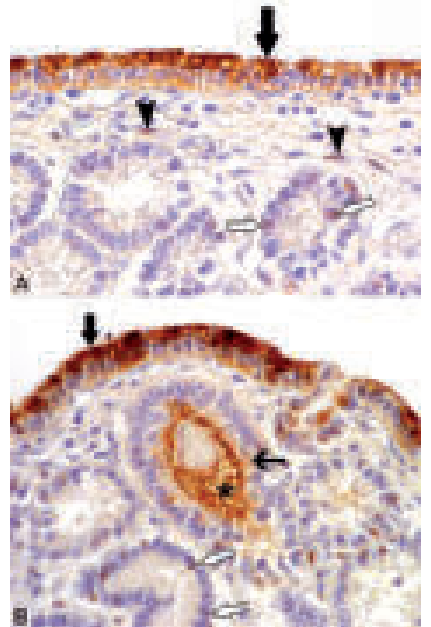

Figs. 4A and B Immunohistochemistry for the detection of $\beta$-defensin: Luminal epithelial cells display a strong cytoplasmic immunolabelling (thick black arrows) and scattered glandular epithelial cells a mild to moderate cytoplasmic immunostaining (thin black arrow). A nuclear immunostaining is observed in small numbers of glandular epithelial cells (white arrows) and stromal cells (arrowheads). The vast majority of luminal or glandular epithelial cells show either a cytoplasmic or a nuclear immunoreaction. Intraluminal glandular secretory products stain strongly immunopositive (asterisk, mare No. 5).

Immunhistologischer Nachweis von $\beta$-Defensin: Die Oberflächenepithelzellen (dicke schwarze Pfeile) zeigen eine starke and vereinzelte glanduläre Epithelzellen (dünner schwarzer Pfeil) eine gering- bis mittelgradige zyoplasmatische Immunoreaktivität. Eine immunhistologische Anfärbung des Kernes liegt in einer geringgradigen Anzahl von Drüsenepithelien (weisse Pfeile) und Stromazellen (Pfeilspitzen) vor. Die größte Anzahl der Oberflächen- und Drüsenepithelien weist entweder eine ausschließlich zytoplasmatische oder eine ausschließlich nukleäre Immunoreaktivität auf. Das intraluminale glanduläre Sekret reagient immunhistologisch positiv (Stern, Stute Nr. 5).

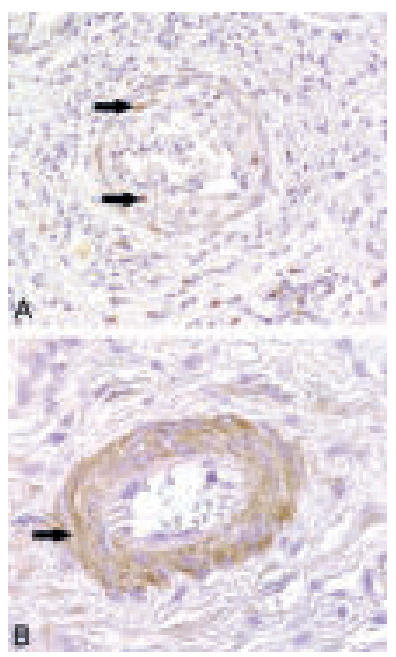

Fig. 5 Immunohistochemistry for the detection of $\beta$-defensin: A) Endometrial artery: A nuclear immunostaining (arrows) is observed in scattered smooth muscle cells of the tunica media (mare No. 5). B) Endometrial artery: The smooth muscle cells of the vascular tunica media (arrow) display a diffuse cytoplasmic immunoreaction (mare No. 2).

Immunhistologischer Nachweis von $\beta$-Defensin: A) Arterie, Endometrium: Eine nukleäre immunhistologische Reaktion (Pfeile) befindet sich im Zellkern vereinzelter glatter Muskelzellen der Tunica media (Stute Nr. 5). B) Arterie, Endometrium: Die glatten Muskelzellen der Tunica media (Pfeil) zeigen eine diffuse zytoplasmatische immunhistologische Reaktion (Stute Nr. 2) 
epithelial cells, the stromal cells and the smooth muscle cells of the tunica media of arteries and veins. In addition, secretory products within glandular lumina stained immunopositive (Figs. 3-4). A positive immunostaining of the luminal epithelium was observed in the 27 cases with a preserved luminal epithelium. In the biopsy of 1 (No. 19) of the 28 mares, the luminal epithelium was lost and thus could not be evaluated. In the remaining 27 cases, the immunostaining was cytoplasmic; the numbers of immunolabelled cells were variable ranging between $3 \%$ and $97 \%$. Two cases (Nos. 6, 23) displayed an additional nuclear immunostaining in $3 \%$ and $10 \%$ of the analyzed cells, respectively.

In 1 biopsy sample (No. 14), the glandular immunostaining could not be evaluated due to the small size and the poor quality of the endometrial sample. Positive immunostaining of the ducts of endometrial glands was detected in 20 of 27 mares (74\%) and encompassed $4-91 \%$ of the analyzed epithelial cells. The immunostaining was cytoplasmic in 15 mares, cytoplasmic and nuclear in 3 mares and nuclear in 2 mares. Mid glands displayed a positive immunoreaction in 6 of 27 mares (22\%); the immunostaining was cytoplasmic in 1 mare and nuclear in 5 mares. The percentage of immunopositive cells ranged from $2 \%$ to $50 \%$. Within basal glands, a positive immunostaining was detected in 2 mares (7\%); this nuclear immunosignal was observed in $11 \%$ and $13 \%$ of the investigated cells. Stromal cells stained immunopositive in 6 mares (22\%); the labelling was restricted to the nucleus and ranged from $2 \%-24 \%$ of the counted cells.

The calculation of the average percentage of immunopositive cells within the evaluated cell populations showed that the highest numbers of immunopositive cells were located within the luminal epithelium and the second largest number within ducts of the endometrial glands.

In 14 mares, variable numbers of endometrial arteries and veins showed positive immunostaining of the tunica media (Fig. 5). The immunoreaction of the smooth muscle cells was cytoplasmic in 13 mares and nuclear in 1 mare. The cytoplasmic immunostaining of vascular smooth muscle cells was less intense than the cytoplasmic labelling of the epithelial cells. The nuclear immunoreaction was observed in scattered cells. Cytoplasmic immunostaining of the tunica media was observed in 6 mares with no angiosclerosis, in 4 mares with mild and in 3 mares with moderate angiosclerosis. The mare with the nuclear immunolabelling of the vascular tunica media showed moderate angiosclerosis.

Interestingly, the vast majority of cells within the immunopositive cell populations, i.e. luminal or glandular epithelium, stromal cells or vascular smooth muscle cells, displayed either a cytoplasmic or a nuclear immunostaining. Only a few glandular epithelial cells with a nuclear immunostaining showed a simultaneous weak cytoplasmic labelling.

\section{Discussion}

This study shows the expression of equine $\beta$-defensin- 1 mRNA and $\beta$-defensin protein in the equine endometrium indicating that also in the mare $\beta$-defensins are important for maintaining endometrial health and fertility.
Antimicrobial peptides including defensins are components of the innate immune system (Schneider et al. 2005, Bruhn et al. 2011 ). In mucous membranes such as the endometrium, they provide the first line of defence to pathogens and are involved in maintaining the physiological milieu (King et al. 2003, Fahey et al. 2008, Lyle 2011). Beta-defensins have been detected in the endometrium of human beings (King et al. 2003, Jorgenson 2005, Das et al. 2007, Fahey et al. 2008) and different species including rats (Alan and Liman 2012), mice (Soboll et al. 2006) and bovine (Davies et al. 2008, Martins et al. 2011 ).

Suppurative endometritis is most commonly caused by a bacterial (Troedsson 2011) and/or yeast infection (Coutinho da Silva and Alvarenga 2011 ). It also develops post breeding or post inseminationem ("post-breeding endometritis") (Schoon et al. 1997, Troedsson 2011), likely attributed to the clearance of excess spermatozoa together with a possible bacterial entry into the uterine lumen (Troedsson 2011). Some mares are predisposed to develop a persistent endometritis ("susceptible mares"), discussed is a multifactorial aetiology with reduced myometrial contractions, anatomical abnormalities and/or alterations of the innate immune response or neutrophilic function as contributing factors (Schoon et al. 1997, Lyle 2011, Troedsson 2011). Non-suppurative lymphoplasmacellular endometritis is an important factor of subfertility in mares and often refractory to treatment (Schoon et al. 1997). In most cases, the underlying aetiology cannot be determined (Schoon et al. 1997). Due to the presence of intralesional plasma cells, an immunological reaction to retained antigens has to be considered. In the present study, no clinical history was available for the majority of mares with endometritis. Reportedly, purulent vaginal discharge was observed in one mare (No. 18) and $\beta$-haemolysing Streptococci and Candida spp. were isolated from a uterine swab of another mare (No. 16). In regard to human $\beta$-defensin-1, it has been shown that genomic or transcriptional differences may result in a higher susceptibility to particular infectious or inflammatory diseases (Prado-Montes de Oca 2010).

Several mares of this study showed the presence of degenerative endometrial lesions, i.e. endometrosis and angiosclerosis. Endometrosis is histopathologically characterized by the presence of periglandular fibrosis and likely results in glandular dysfunction (Schoon et al. 1997, Lehmann et al. 2011 ). The initiating cause for the development of endometrosis is uncertain; it represents an age associated irreversible condition (Schoon et al. 1997). Degenerative vascular alterations (arteriosclerosis, phlebosclerosis) are a common finding in endometrial biopsies, develop in association with increasing age and parity and can contribute to subfertility by causing reduced perfusion (Schoon et al. 1997). Information in regard to parity was only available for a few mares of this study. One maiden mare (No. 22) had no evidence of angiosclerosis, the other maiden mare (No. 26) displayed mild endometrosis; the mare with 12 foals (No. 28) had moderate angiosclerosis.

The presence of equine $\beta$-defensin mRNA and protein in healthy endometrial samples as well as in endometrial tissue with inflammatory or degenerative alterations suggests a constitutive expression of $\beta$-defensin in the equine endometrium. For the detection of $\beta$-defensin protein, an anti human 
$\beta$-defensin-2 antibody was used that had been shown previously to cross-react with equine tissue (Yasui et al. 2007). This antibody was applied, since equine $\beta$-defensin- 1 displays the greatest peptide sequence homologies to human $\beta$-defensin-2 and porcine $\beta$-defensin-1 (Davis et al. 2004, Looft et al. 2006) and no commercial antibody for labelling of equine $\beta$-defensin-1 was available at the time of this study.

In the present study, no quantification of the mRNA expression in the equine endometrium was performed. In the human endometrium, $\beta$-defensins show changes in regard to their expression levels that correspond to different stages of the menstrual cycle (King et al. 2003, Jorgenson 2005). Furthermore, the expression of endometrial defensins can be up- or downregulated by the exposure to inflammatory mediators (King et al. 2002) or pathogen-associated molecular patterns (King et al. 2002, Jorgenson 2005).

In this investigation, a positive immunostaining of the equine endometrium for $\beta$-defensin protein was observed in luminal and glandular epithelial cells (cytoplasm and/or nucleus), in glandular secretory products, in the nucleus of stromal cells as well as in vessels. By immunostaining of the rat endometrium, Alan and Liman (2012) detected $\beta$-defensins- 1, -2, -3 and -4 in epithelial and stromal cells as well as vessels. In comparison to the results of this study, stromal cells displayed an additional cytoplasmic immunostaining and in vessels endothelial cells (nucleus or cytoplasm) were immunopositive; an immunoreaction of endometrial vascular smooth muscle cells was not reported (Alan and Liman 2012). The present investigation revealed no conclusive immunostaining of vascular endothelial cells. The evaluation of vascular endothelial cells, however, was not possible in all vessels due to section artefacts.

The detection of $\beta$-defensin protein in several cell populations of the equine endometrium suggests multiple functions of $\beta$-defensin in the equine endometrium.

The presence of $\beta$-defensin protein in the cytoplasm of epithelial cells and within secretory material is consistent with the intracellular synthesis of $\beta$-defensin followed by its intraluminal secretion, most likely as part of the uterine innate immune defence. Similarly, in the human mid-luteal endometrium, the luminal and glandular epithelium as well as glandular secretions were immunopositive for human $\beta$-defensin- 1 (Das et al. 2007).

Notably in this investigation, immunostaining for $\beta$-defensin was also observed in the tunica media of endometrial vessels. Studies on the defensin expression in vascular smooth muscle cells are rare; in the few reported studies $\alpha$-defensins were investigated (Barnathan et al. 1997, Nassar et al. 2012). In addition, Alan and Liman (2012) describe a positive $\beta$-defensin- 1 immunostaining of vascular smooth muscle cells in pulmonary arteries of rat tissue used as positive control; it is not mentioned if the immunoreaction was located in the nucleus or cytoplasm. In this study, in all but 1 case immunoreactive endometrial vessels showed a cytoplasmic labelling. Experimental studies on rat aortic rings revealed an inhibitory effect of $\alpha$-defensin on smooth muscle contraction (Nassar et al. 2012). The proposed mechanism is a receptor-mediated intracellular uptake of $\alpha$-defensin from the circulation followed by the activation of intracellular signal transduction (Nas- sar et al. 2012). Based on our investigations, it cannot be determined if the detected $\beta$-defensin is produced in the endometrial vascular smooth muscle cells or if it is internalized from the circulation. Not only $\alpha$-defensin (Panyutich et al. 1993), but also $\beta$-defensin (Bensch et al. 1995), is detected in the human blood plasma. To the authors knowledge, studies investigating the presence of $\alpha$-or $\beta$-defensin in the equine blood plasma are not been published so far.

The nuclear immunostaining of epithelial and stromal cells as well as vascular smooth muscle cells of the equine endometrium indicates a nuclear translocation of $\beta$-defensin and its involvement in the regulation of gene transcription. Some sequence homology to a nuclear translocation signal has been found in human $\beta$-defensin- 1 (Bick et al. 2007). In addition to the nuclear $\beta$-defensin immunostaining observed in cell populations of the rat endometrium (Alan and Liman 2012), a positive nuclear immunostaining for $\beta$-defensin was also observed in keratinocytes of the human skin (Bick et al. 2007) and in neoplastic tissue of human beings including tumour cells of pleomorphic salivary adenomas (Pantelis et al. 2009) and salivary carcinomas (Wenghoefer et al. 2008). In comparison to normal human salivary gland tissue that displays a cytoplasmic immunoreaction for human $\beta$-defensin- 1 in ductal epithelial cells, pleomorphic salivary gland adenomas showed a nuclear immunostaining of neoplastic cells and contained a significantly reduced amount of human $\beta$-defensin- 1 mRNA (Pantelis et al. 2009). These findings suggest that nuclear translocation of human $\beta$-defensin- 1 is associated with an inhibition of its gene transcription (Pantelis et al. 2009).

In the investigated equine endometrium, the vast majority of cells with a nuclear immunostaining showed a negative cytoplasmic immunostaining and only a few a concurrent weak cytoplasmic staining. The functional significance of a nuclear location of $\beta$-defensin in cell populations of the equine endometrium has to be investigated in further studies.

In this study, the numbers of $\beta$-defensin immunopositive endometrial epithelial and stromal cells varied between individual animals. Quantitative and qualitative differences in the immunoreaction may be explained by collection of the endometrial tissue during different stages of the endometrial cycle and the presence of inflammatory and/or degenerative endometrial diseases. In addition, previous breeding or the application of intrauterine treatments have to be considered as possible additional factors that could influence the $\beta$-defensin expression.

Individual factors regulating the $\beta$-defensin expression in the equine endometrium have to be examined in future investigations using homogenous study groups and defined conditions.

In summary, this study confirms the expression of $\beta$-defensin mRNA and protein in the equine endometrium and thus will provide the basis for further investigations into the regulation of $\beta$-defensin expression in the endometrium of the mare.

\section{Acknowledgment}

The authors thank Maritta Wipplinger for performing the immunohistochemistry and the histology laboratory for excellent technical support. 


\section{References}

Alan E. and Liman N. (2012) Immunohistochemical localization of beta defensins in the endometrium of rat uterus during the postpartum involution period. Vet. Res. Commun. 36, 173-185

Barnathan E. S., Raghunath P. N., Tomaszewski J. E., Ganz T., Cines D. B. and Higazi A. A. -R. (1997) Immunohistochemical localization of defensin in human coronary vessels. Am. J. Pathol. 150, 1009-1020

Bensch K. W., Raida M., Mägert H.-J., Schulz-Knappe P. and Forssmann W.-G. (1995) hBD-1: a novel $\beta$-defensin from human plasma. FEBS Letters 368, 331-335

Bick R. J., Poindexter B. J., Buja L. M., Lawyer C. H., Milner S. M. and Bhat S. (2007) Nuclear localization of HBD-1 in human keratinocytes. J. Burns Wounds 24, 7:e3

Bruhn O., Regenhard P., Michalek M., Paul S., Gelhaus C., Jung S., Thaller G., Podschun R., Leippe M., Grötzinger J. and Kalm E. (2007) A novel horse alpha-defensin: gene transcription, recombinant expression and characterization of the structure and function. Biochem J. 407, 267-276

Bruhn O. (2009) Defensine des Pferdes. Inaugural Dissertation, Institut für Tierzucht und Tierhaltung der Agrar- und Ernährungswissenschaftlichen Fakultät der Christian-Albrechts-Universität zu Kiel, pp. 1-147.

Bruhn O., Paul S., Tetens J. and Thaller G. (2009) The repertoire of equine intestinal alpha-defensins. BMC Genomics 23, 10:631

Bruhn O., Grötzinger J., Cascorbi l. and Jung S. (2011) Antimicrobial peptides and proteins of the horse - insights into a well-armed organism. Vet. Res. 42,98

Coutinho da Silva M. A. and Alvarenga M. A. (2011) Fungal endometritis. In: Equine reproduction. McKinnin A.O., Squires E.L., Vaala W.E. and Varner D.D. Eds., 2nd Ed., volume 2, Wiley-Blakkwell, Chichester, West Sussex, PO19 8SQ, UK, 2643-2651

Das S., Vince G. S., Lewis-Jones I., Bates M. D. and Gazvani R. (2007) The expression of human alpha and beta defensin in the endometrium and their effect on implantation. J. Assist. Reprod. Genet. 24, 533-539

Davis E.G., Sang Y. and Blecha F. (2004) Equine $\beta$-defensin-1: full length cDNA sequence and tissue expression. Vet. Immunol. Immunopathol. 99, 127-132

Davies D., Meade K. G., Herath S., Eckersall P. D., Gonzalez D., White J. O., Conlan R. S., O'Farrelly C. and Sheldon I. M. (2008) Tolllike receptor and antimicrobial peptide expression in the bovine endometrium. Reprod. Biol. Endocrinol. 6, 53

Erdmann S., Ricken A., Merkwitz C., Struman I., Castino R., Hummitzsch K., Gaunitz F., Isidoro C., Martial J. and Spanel-Borowski K. (2007) The expression of prolactin and its cathepsin Dmediated cleavage in the bovine corpus luteum vary with the estrous cycle. Am. J. Physiol. Endocrinol. Metab. 293, E1365E1377

Fahey J. V., Wright J. A., Shen L., Smith J. M., Ghosh M., Rossoll R. M. and Wira C. R. (2008) Estradiol selectively regulates innate immune function by polarized human uterine epithelial cells in culture. Mucosal Immunol. 1, 317-325

Ganz T., Selsted M. E. and Lehrer R. I. (1990) Defensins. Eur. J. Haematol. 44, 1-8

Gersemann M., Wehkamp J. and Stange E. F. (2012) Innate immune dysfunction in inflammatory bowel disease. J. Intern. Med. 271, 421-428

Han W., Wang W., Mohammed K. A. and Su Y. (2009) $\alpha$-defensins increase lung fibroblast proliferation and collagen synthesis via the $\beta$-catenin signalling pathway. FEBS J. 276, 6603-6614

Hornickel I. N., Kacza J., Schnapper A., Beyerbach M., Schoennagel B., Seeger J. and Meyer W. (2011) Demonstration of substances of innate immunity in the oesophageal epithelium of domesticated mammals: Part I - Methods and evaluation of comparative fixation; Part II- Defence mechanisms, including species comparison. Acta histochem. 113, 163-174, 175-188

Jorgenson R. L. (2005) The innate immune response and toll-like receptors in the human endometrium, PhD Thesis, University of Missouri-Columbia, USA, 1-236

Kenney R. M. and Doig P. A. (1986) Equine endometrial biopsy. In: Current therapy in theriogenology, Morrow D. A. Editor, 2nd Ed., WB Saunders, Philadelphia, USA, 723-729

King A. E., Fleming D. C., Critchley H. O. D. and Kelly R. W. (2002) Regulation of natural antibiotic expression by inflammatory mediators and mimics of infection in human endometrial epithelial cells. Mol. Hum. Reprod. 8, 341-349

King A. E., Critchley H. O. D. and Kelly R. W. (2003) Innate immune defences in the human endometrium. Reprod. Biol. Endocrinol. 1, 116
Klein C., Rutllant J. and Troedsson M. H. T. (2011) Expression stability of putative reference genes in equine endometrial, testicular, and concepus tissues. BMC Res. Notes 4, 120

Lehmann J., Ellenberger C. Hoffmann C., Bazer F. W., Klug J., Allen W. R. , Sieme H. and Schoon H.-A. (2011) Morpho-fuctional studies regarding the fertility prognosis of mares suffering from equine endometrosis. Theriogenology 76, 1326-1336

Lehrer R. I. and Ganz T. (2002) Defensins of vertebrate animals. Curr. Opin. Immunol. 14, 96-102

Looft C., Paul S., Philipp U., Regenhard P., Kuiper H., Distl O., Chowdhary B. P. and Leeb T. (2006) Sequence analysis of a $212 \mathrm{~kb}$ defensin gene cluster on ECA 27q17. Gene 376, 192-198

Ludwig S., Schoon D., Aupperle H., von Reiswitz A. and Schoon H.-A. (2001) Angiopathies in the equine endometrial biopsy - a marker for extrauterine vascular lesions? Pferdeheilkunde 17, 608-614

Lyle S. K. (2011) Immunological considerations. In: Equine reproduction. McKinnin A. O., Squires E. L., Vaala W. E. and Varner D. D. Eds., 2nd Ed., volume 2, Wiley-Blackwell, Chichester, West Sussex, PO19 8SQ, UK, 2587-2596

Martins T. da M., da Paixão T. A., Costa A., Pires A. de C., Santos R. L. and Borges Á. M. (2011) Postpartum toll-like receptors and bdefensin 5 mRNA in the endometrium of Holstein cows. Vet. Immunol. Immunopathol. 139, 277-281

Nassar T., Akkawi S, Bar-Shavit R., Haj-Yehia A., Bdeir K., Al-Mehdi A.-B., Tarshis M. and Higazi A. A.-R. (2012) Human $\alpha$-defensin regulates smooth muscle cell contraction: a role for low-density lipoprotein receptor-related protein/ $\alpha 2$-macroglobulin receptor. Blood 100, 4026-4032

Panyutich A. V., Panyutich E. A., Krapivin V. A., Baturevich E. A. and Ganz T. (1993) Plasma defensin concentrations are elevated in patients with septicemia or bacterial meningitis. J. Lab. Clin. Med. 122, 202-207

Pantelis A., Wenghoefer M., Haas S., Merkelbach-Bruse S., Pantelis D., Jepsen S., Bootz F. and Winter J. (2009) Down regulation and nuclear localization of human $\beta$-defensin- 1 in pleomorphic adenomas of salivary glands. Oral Oncol. 45, 526-530

Prado-Montes de Oca E. (2010) Human $\beta$-defensin 1: a restless warrior against allergies, infections and cancer. Int. J. Biochem. Cell. Biol. 42, 800-804

Schoon H.-A., Schoon D. and Klug E. (1992) Uterusbiopsien als Hilfsmittel für Diagnose und Prognose von Fertilitätsstörungen der Stute. Pferdeheilkunde 8, 355-362

Schoon H.-A., Schoon D. and Klug E. (1997) Die Endometriumbiopsie bei der Stute im klinisch-gynäkologischen Kontext. Pferdeheilkunde 13, 453-464

Schneider J. J., Unholzer A., Schaller M., Schäfer-Korting M. and Korting H. C. (2005) Human defensins. J. Mol. Med. 83, 587-595

Soboll G., Schaefer T. M. and Wira C. R. (2006) Effect of Toll-like receptor (TLR) agonists on TLR and microbicide expression in uterine and vaginal tissues of the mouse. Am. J. Reprod. Immunol. $55,434-446$

Troedsson M. H. T. (2011) Endometritis. In: Equine reproduction. McKinnin A. O., Squires E. L., Vaala W. E. and Varner D. D. Eds., 2nd Ed., volume 2, Wiley-Blackwell, Chichester, West Sussex, PO19 8SQ, UK, 2608-2619

Wenghoefer M., Pantelis A., Dommisch H., Götz W., Reich R., Bergé S., Martini M., Allam J. P., Jepsen S., Merkelbach-Bruse S., Fischer H. P., Novak N. and Winter J. (2008) Nuclear hBD-1 accumulation in malignant salivary gland tumours. BMC Cancer 8: 290

Yamaguchi Y., Nagase T., Tomita T., Nakamura K., Fukuhara S., Amano T., Yamamoto H., Íde Y., Suzuki M., Teramoto S., Asano T., Kangawa K., Nakagata N., Ouchi Y. and Kurihara H. (2007) ß-defensin overexpression induces progressive muscle degeneration in mice. Am. J. Physiol. Cell Physiol. 292, C2141-C2149

Yasui T., Fukui K., Nara T., Habata I., Meyer W. and Tsukise A. (2007) Immunocytochemical localization of lysozyme and beta-defensin in the apocrine glands of the equine scrotum. Arch. Dermatol. Res. 299, 393-397

Dr. Sandra Schöniger

Dipl. ACVP, Fachtierärztin für Pathologie

Institut für Pathologie

Veterinärmedizinische Fakultät

Universität Leipzig

An den Tierkliniken 33

04103 Leipzig

sandra.schoeniger@vetmed.uni-leipzig.de 